\title{
Humor, Happiness and Work Relationship among Faculty Members in Islamic Higher Education of Indonesia
}

\author{
Fahmi Gunawan ${ }^{1}$ Alimin Alimin²
}

Institut Agama Islam Negeri Kendari, Indonesia. E-mail: founawanp@gmail.com

${ }^{2}$ Universitas Islam Negeri Syarif Hidayatullah Jakarta, Indonesia. E-mail: aliminmesra@gmail.com

\begin{tabular}{l} 
ARTICLE INFO \\
\hline Keywords: \\
Humor; happiness; \\
relationship; lecturer; \\
Islamic Higher Education \\
\\
How to cite: \\
Gunawan, F., et.al. (2018). \\
Humor, Happiness and \\
Work Relationship among \\
Faculty Members in \\
Islamic HigherEducation \\
of Indonesia, $4(2), 106-$ \\
122. \\
DOI: \\
http://dx.doi.org/10.31332/ \\
lkw.v4i2.904
\end{tabular}

\begin{abstract}
Humor is important among educators to refresh their mind from busy work, strengthen friendship and interpersonal relationship, create happiness, and to improve working performance and cooperation of both personal and professional matters. This study aims to examine the humor in the perspective of linguistics and psychology, especially the semantic aspect among colleagues of lecturers in Islamic universities of Indonesia. A qualitativedescriptive method was employed to analyze data which were collected through participants' observation and in-depth interview. The results indicate that to create humor from a linguistic perspective, lecturers used polysemy and homonym aspects as part of the language game. Polysemy is only a word while homonym is a word, abbreviation, and acronym. The words that indicate polysemy is margacinta, hawa, and kopi, while the words that indicate homonyms in the form of words maroko, farj, and tabrakan. On the other hand, the abbreviation homonymy is found in the phrases of peraturan pemerintah and pembimbing akademik, and the acronyms are found in words akper, jatol, jaka, marisa, and jelita. This language game then creates a joyful atmosphere among lecturers which ultimately affects their interpersonal relationships. The proximity of interpersonal relations also has implications for better employment relations and increased productivity to do works assigned to them. Finally, this research confirms that language games such as polysemy and homonymy can also be used to create humor aimed not only to refresh mind but also to create happiness and improve work performance to increase productivity in universities.
\end{abstract}

\section{Introduction}

As one important element of a college, lecturers have a tough task to be able to educate the nation's youth. The tasks are fully contained in national education law and known as Tri Dharma Perguruan Tinggi, namely education and teaching, research and community service (Yuliawati, 2012). Tri Dharma duty is what makes a lecturer has a very high level of mobility and busyness (Hairuddin, Gani, Sinring, \& Arifin, 2017). This is because, in addition to teaching, he/she must also conduct research and community service at once. If the number of teaching hours is more than 30 credits, the time to do the research becomes less. As a result, he/she has to take the 
time to research outside of college. This means that time with the family must be sacrificed for the realization of this tri dharma duty. It should also be admitted that the portion of lecturer research is different. The higher the functional level of a lecturer, the higher the portion of the research they must do. However, it is clear that research is an obligation that must be done by a lecturer, although the functional position is still low. The fact that a lecturer produces certain teaching material based on the research project and his/her ingenuity is the result of a research product is understandable.

The lecturers' job is different from other jobs, like farmers, fishers, or employees who finish their job along with the time ends in a day. This is because of farmers, fishermen; private employees just rely on the physical strength that will be regained after returning home. On the other hand, the work of a lecturer relies on the mind, physical, psychic, and spiritual power. Thinking takes time and will not necessarily be fresh after a physical rest. Thus, even though their body is physically resting, they may not be able to rest because the lecturers keep thinking something for their research. This means that a lecturer desperately needs relaxation and rejuvenation wherever he/she is.

Humor is one option to refresh our mind. In addition to its entertainment, humor can serve as a recreational means. Besides, humor can serve as a bonding tape, friendship trigger, educational vehicle, social criticism and productivity improvement (Richards, 2010). This is because humor occurs in a free atmosphere of thinking, speaking, and expression. Humor for a lecturer, especially in Islamic Higher Education, for example, is created for releasing stress and tiredness after teaching, helping to stimulate communication and relationship. Not infrequently, through humor, we find that a lecturer often gets the idea to write. Thus, humor is essentially a person's way to increase his passions. Humor is a universal phenomenon, yet every nation, tribe, or group has a different perception of what is considered funny. Humor is defined as a communication that creates humor, entertains and stimulates us to laugh or tend to laugh (Banas, Dunbar, Rodriguez \& Liu, 2011). It often comes suddenly. It is not planned hand. This is because people have remarkable sensitivity when it comes to humor. Humor is defined as the quality of something such as elegance, fun, and humor (Lebowitz, Suh, Diaz \& Emery, 2011). Humor can make people laugh and happy when it contains one or more of the following four elements; overstatement problems, mischief, shock, which results in embarrassment. The four essentials above can be accomplished through language units created consciously by the speakers, but it is also supported by the conversation context (Wijana, 2002).

In a linguistic perspective, the funny or humorous feeling arises from the ambiguity of the word, such as polysemy and homonymy which is created by the speakers to others (Martin \& Ford, 2018). Based on the above concept, ambiguity in language has a central position in the creation of humor because of the ambiguity both phonological and grammatical relating to two or more concepts in which each has a different reference frame. The language aspects that can be classified in ambiguity are polysemy, homonymy, amphiboly phrase, and idiom (Wijana, 2002). Polysemy is a word or phrase that contains more than one meaning. Polysemy occurs in the use of word or word combination in the context of the different speech 
(Cruse, 2011). Thus, polysemy comes from a single word and its meaning which is still related. The word 'head' for example can mean a lot, although the main meaning is the part of the human body that is above the neck. Another example is the word 'fall.' 'Fall' or jatuh can mean a lot, as in the following examples. (1) He fell. (2) The anniversary of the Ministry of Religious Affairs falls in January. (3) He fell ill after Eid al-Adha. (4) The test score falls. Falling on example (1) means down or down quickly because of Earth's gravity (both when it is still in a descending motion and after arriving at the ground). Falling in examples (2), (3), (4) means to coincide with, decrease, and become ill. Homonyms are two or more words of the same shape and different meanings (Thomas, 2014). The form here can refer to writing and speech sounds. The first is called homograph, while the second is called the homophone. Homophone refers to two or more words that have a different meaning (Wijana, 2002). Associated with the nature of the ambiguity, homophones are often exploited in the discourse of humor. The words which have the same sound but have different meaning are potential to disrupt the perception of the interlocutor to bring laughter from the other speaker.

The importance of the humor role in the very busy lecturers' life is the main reason for this research. In fact, most of the humor-related studies of happiness are discussed from a psychological perspective. The major theme is how humor influences happiness (Martin et al. 2003, Liu, 2012; Cann \& Collette, 2014; Ford et al., 2014; Yue et al. 2014; Ford et al., 2017). Is the effect positive or not? Most of the research that examines the relation of humor and happiness refers to the famous humor theory of a psychologist; Martin et al. (2003) classify humor into two kinds, namely adaptive humor and maladaptive humor. On the other hand, humor research and employee relationships are also discussed from a psychological perspective. The great theme is how humor affects the working relationship between an employee and another employee (Holmes \& Marra, 2002; Dick \&Holtzman, 2013; Kurtz \& Algoe, 2015).

On the other hand, the research of humor from a linguistic perspective has also been widely discussed. Most of the research explains that humor can also be analyzed from a linguistic perspective because it includes language as a means or container to create, express and develop humor. One way to create humor is to use language games (Wijana, 2002; Yuniawan, 2005; Wilujeng, 2013). The game of the language in question is producing a speech which disturbs the nature of a language, especially in phonological, pragmatic and semantic aspects (Puspitasari, 2013, Kusno, 2014; Alifianita, T., Lukmantoro, T., Sos, S., \& Si, M. 2016; Gunawan, 2016). This disturbance is purposively done to create joke for the people who listen to it, so they can laugh and feel happy. Also, there are not a lot of research about humor which focuses on the lecturers in university. If any, the research is still very limited, such as research on humor lecturers in Turkey (Tumkaya, 2006) and humor teachers in China (Wu \& Chan, 2013). This is because most studies focus on humor in classroom learning as found in Indonesia (Rohmadi, 2010; Usman et al. 2016), Hong Kong (Li, 2015), Pakistan (Nayyar \& Zeeshan, 2017), Iran (Alavinia, 2017), and the result indicates that humor can improve student's motivation, final results, and achievement and can reduce student stress in learning. Humor research in linguistic and psychological perspectives is still very rare. This research is advanced research 
that discusses humor in linguistic and psychology perspectives among lecturers at Indonesian Islamic universities. If previous research discusses the humor of the phonological aspect and its relation to happiness (Gunawan \& Wahyuni, 2017), this research discusses the humor of the semantic aspect, especially on polysemy and homonymy aspects as well as its relation to happiness and working relationships among fellow lecturers at Indonesian Islamic universities. Thus, this study aims to examine the humor, happiness, and proximity of work among lecturers at Indonesian Islamic universities in linguistic and psychological perspectives.

\section{Literature Review}

Humor is defined extensively by many scholars. Humor is defined as "that quality of action, speech, or writing which excites amusement; funny habit, jocularity, facetiousness, comicality." Humor is defined as the quality of something such as a performance or a joke that elicits pleasure, fun, and humor (Carroll, 2014). In recent times, there are two aspects of humor; they are adaptive and maladaptive (Martin et al., 2003; Yue et al. 2014). Adaptive humor refers to humor that is advantageous to psychological well-being, namely affiliative and self-enhancing humor (Dyck \& Holtzman, 2013; Hampes, 2016; Ford et al. 2017). Affiliative humor tends to engage in unprompted humorous jokes to create enjoyment, diminish interpersonal tension and give a hand to the relationship. It could boost interpersonal cohesiveness as well. Self-enhancing humor means the tendency to locate enjoyment from life incongruities (Ford et al. 2014).

On the other hand, maladaptive humor is hurtful to well-being. They are aggressive humor and self-defeating humor. Aggressive humor is humor for manipulating others, such as disparagement, derision, ridicule, and mockery (Chefneux, 2015). Self-defeating humor refers to the tendency to grovel to others and try to amuse them by making fun at their weakness (Stieger et al. 2011). To sum up, adaptive humor styles are positively correlated with happiness, while maladaptive humor styles are in negative association with happiness. Specifically, affiliative humor and self-enhancing humor are believed to be positively correlated with happiness elements. Meanwhile, aggressive and self-defeating humor is related to elements leading to lower happiness. Then, this theory is combined with Wijana's theory on polysemy and homonymy from a linguistic perspective.

Two well-known semantic problems are homonymy and polysemy (Vetter \& Viebahn, 2016). Bank in river bank and Bank of Indonesia are homonymous. They share no meaning. They have a function as two unrelated words. River bed and hospital bed seem to be somehow semantically linked. It is a case of polysemy. There are two hypotheses of polysemy theory (Satta, 2018). First, a literal meaning from which the other meanings are derived (a linear explanation). Second, there is a core meaning with specific senses triggered either by the context or by rules. Lexicographers are aware of polysemy and homonymy because of their semantic closeness and referential dispersion when words are considered out of context. In everyday utterance, our usage of words is almost never ambiguous. On saying something or hearing something, "The Bank of Indonesia has increased its rates." The other meanings of the bank are probably not even considered. Dictionaries consist of words and phrases which out of context. Polysemes under one entry only and homonyms are usually listed under different entries, but not always. 


\section{Method}

This study used descriptive qualitative paradigm utilizing cases study method. To collect data, researchers used interviewing, observing and document study. Data collection activities are taken from the humor among lecturers at Institut Agama Islam Negeri (IAIN) Kendari. There are twenty people in total which consist of fifteen females and five male lecturers. They are about 25-50 years old. The lecturers' humor is the lecturers' utterances that give rise to humor and make the listener laugh. This humor can happen in the street, in the mosque, in front of the integrated lecture building, in the campus corridors, in the parking lot, inside the seminar room. Observation of some data shows there are various types of language aspects that are often used to create humor, aspects of sound irregularities, polysemy, euphemism, and homonymy according to the scope of the discussion. In this study the question of polysemy and homonym is to be discussed and, therefore, lecturers' utterances containing polysemy and homonymy are discussed only, while others are ignored. In analyzing data, this is called by the reduction of the data (Myles, Huberman, and Saldana, 2013).

After discussing the humorous data from a linguistic perspective, the data is discussed again in a psychological perspective. The data was then analyzed using the theory of humor (Martin et al. 2003) which divides humor into two types, positive humor, and negative humor. Positive humor is also called adaptive humor while negative humor is also called maladaptive humor. This type of positive humor is classified into two, namely affiliative and self-enhancing humor. The type of negative humor is classified into two; aggressive humor is self-defeating humor. Positive humor positively correlates with happiness while negative humor negatively correlates with happiness. From this analysis, the researcher will find whether the humor of lecturers at IAIN Kendari as one of the Islamic universities in Indonesia are affiliative humor and self-enhancing humor that can bring happiness or vice versa or humor aggressive and self-defeating humor that will not bear happiness, even can lead to tense among those who rise humor.

\section{Findings}

The lecturers' humor is sudden and natural as it can be viewed from a semantic perspective. Semantics is the study of meaning. Polysemy and homonymy are part of semantics. Polysemy refers to the words that differ in meaning, but they are caused by the context of their use in the sentence (Wijana, 2002). The word 'head' for example, can be expanded with other words, such as principals, head offices, and branch heads. The word head is polysemy and has similarly close connections. The concept of the head refers to the part of the human limbs that lie at the top and the most important part of the body. This concept is then applied to the new word, the principal, the head of the office, and the head of the branch. Thus, it can be said that the head which means the uppermost part of the body is the primary meaning and the other meaning is the secondary meaning. A homonym is a word that has the same form and utterance but has a different meaning. If there are two or more words of the same shape and different meaning, it is called a homonym. The form here can be the written form or the pronunciation. The first is called homograph, while the second is called the homophone. For example, 'bisa', 'kata', 'abang', 'beruang', 
'ruanggelap' has more than one meaning. The word 'bisa' besides having the meaning of 'snake poison' can also refer to 'the ability to do something'. The word 'abang' can mean 'older brother' and 'red color'. Beruang can mean 'have money' and can also mean 'animal names'. Ruang gelap can mean 'dark room' can also mean 'place to print photos'.

\section{Polysemy and Homonymy}

In lecturers, polysemy and homonymy discourse are often used to provoke the humor of the listeners. It is said to be funny because this meaningfully double word is often misunderstood and misled by the listeners. The meaning of one word according to the person who gives humor is not the same as the meaning by the listeners. This means that the meaning of the word is very potential to disrupt the perception of the opponent. The resulting chaos is often the result of the suspected interpretation of meaning by the listeners or the other person. The following 1-3 data will display the polysemy.

Data (1)

Location : Meeting Room for Research and Community Service

Context : Discussion in the language laboratory room. There is a student who wants to consult her thesis to his lecturer. The title of the thesis is the Review of Islamic Law Against Pregnancy in Margacinta Village of South Konawe.

Udin Where will the research be done?

Ana In Margacinta

Udin Where is it? Margasatwa, Margareta..wkwkwkwk

Data (2)

Location : Meeting Room

Context : Lecturers' orientation

Asriana : Welcome Mr. Cahyo

Cahyo : You may call me Agung. Thanks, Pak

Asriana : I am HawaSir..notPak...wkwkwkwk

Cahyo : As long as it is not hawapanas or hawadingin..hehehe

Asriana : Hawapembawakebahagiaanandkegembiraan

Data (3)

Location : Meeting Room

Context : Talk about a place to have a coffee together

Abdul : Ris, How about we meet for ngopi?

Haris : Sure, at the canteen

Abdul : Come on; I am at the canteen

Haris : Rifah likes ngopi 
Abdul : As long as it is not ngopiand paste... hehehehe

Data (1-3) indicates that the source of funny laughter comes from a double meaning word which is marga in data (1), Hawa in data (2) and ngopi in data (3). Marga on the data (1) initially refers to the meaning of the name of a small village, Margacinta in Moramo of Konawe Selatan District. However, to create joy atmosphere, the word is then pronounced into margasatwa that refers to the name of a protected zoo. The word hawa on data (2) applies the same pattern. This word refers to the meaning of women because the first human grandmother in the world named Sitti Hawa. To make a joke, the speaker misleads the original meaning of hawato the air or the surrounding environment like hot or cold air and then leads to the word of happiness because women (hawa) always bring happiness. The word ngopi in the data (3) also gives rise to humor because the conversation initially discusses the types of coffee, but then the speakers play the word ngopi to be copy and paste activity. Furthermore, the following 4-6 data will describe a one-word homonym.

Data (4)

Location : Language Laboratorium Room

Context : A discussion between the presenter and TOEFL participants during Lecturers' Training

Hilal : What is the most dangerous country in the world?

Participant : America, Japan, Russia

Hilal : No

Participant : So?

Hilal : Maroko

Participant : Why?

Hilal : Maroko can cause heart disease, lung cancer, and impotent.

Data (5)

Location : Unified building courtyard

Context : Talking about the proverb stated that after difficulty, there will always be easiness.

Muiz : Li kulli Dhaiqin Farj. Wa likulli farj miftah. Wa miftahul farj zakar "every difficulty, there is always a way to solve it. And in every breakout, there is a key. And the key of farji is zakar."

Akbar : Wkwkwkwk

Data (6)

Location : Language Center Building

Context : The conversation between two lecturers about the language use of their students.

Maus : Sir, my modules are tabrakan. 


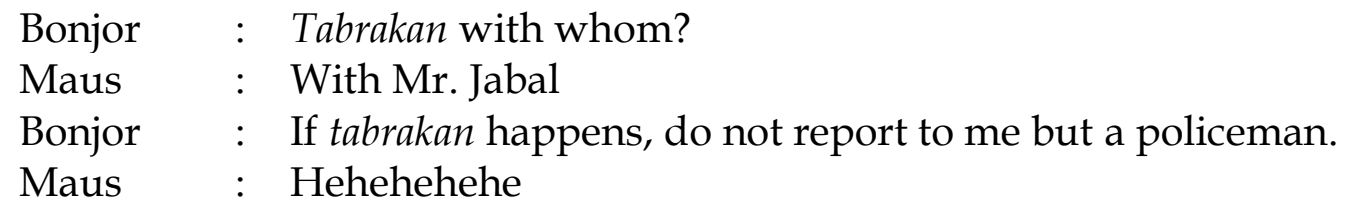

Data (4-6) illustrates the homonym case; the words with similar sound and written form, but they have a different meaning. Homonymy is often used to create funny or humorous stories. The joyful part appears when the speaker plays guessing game to the listeners in a workshop. The speaker asks the participants about which country is the most dangerous in the world. The participants seem to think hard. Some of them responded to Russia, Japan, and other countries as the most dangerous country in the world. Then the speaker also said that the most dangerous country in the world is Maroko (smoking in Indonesia) because it can cause heart disease, lungs cancer, and impotent. This instantly made all the participants laughed out loud because they did not expect the playful answers. The same case also applies to farj in data (5). Farj indeed has many meanings; exit, open and vagina. The initial meaning of the data (5) refers to the exit. This is because indeed every difficult thing has solution or way out and the way out has a key. What makes the participants laugh is the emergence of the word zakar which means penis. If there is a word 'zakar', it is the word 'farj' means vagina. Data (6) also shows humor. The humor comes from the double meaning of the word 'tabrakan' (crash). The crash that was originally meant to be an accident was then spoiled into some lecture schedules done at the same time.

In addition to one-word homonymy, here are some examples of homonyms consisting of abbreviation and acronyms. The abbreviation is an abbreviation of the initial letters while the acronym is the linguistic unit of the result of the abbreviation in a certain way. When viewed from the delivery of intent or meaning, the use of acronyms has a high side of effectiveness, such as word posyandu, siskamling, kades, and so forth. Rural residents who are not proficient in the Indonesian language often use acronyms even if they do not understand the form of the extension. Similarly, it applies to other abbreviations like KTP (identification card) and SIM (driving license). The tendency of people to create acronyms or abbreviations seems to be used to create humor in the humor discourse. The absence of clear rules in the rules of acronym formation makes people self-serving in creating new words as a result of the formation of an acronym which is then becoming homonymy to elicit the laughter of the person who listens to it. The following data (7) will show a temporary abbreviation and data (8-12) displaying the acronym.

Data (7)

Location : Meeting Room for Research and Community Service

Context : Faizah is presenting her proposal entitled effectiveness of academic supervisor (PA). At the time of explaining the background, he mentioned that the effectiveness of the PA lecturer was based on 
the rules.

Izzah : PP RI Number 5 Year 1980 set about the effectiveness of PA lecturers

Ajam : It is dangerous if we mention PP (government regulation) all the time in this room.

Saha : Be careful to mention PA

Izzah : Why?

Saha : PA means stupid, and it stands for pendek akal.

Data (8)

Location : Lecturers' room

Context : Discussion about orientation

Ajam : I have a friend of mine. She ever took the same course, and we attend the course together. It is AKPER Kendari

Wija : Which is Akademi keperawatan you mean?

Ajam : No it is Akademi Keperawanan..wkwkwkw

Data (9)

Location : Meeting Room for Research and Community Service

Context : A lecturer's interview about students' civic education knowledge.

Ajam : What is your tribe?

Ruli : Javanese Sir. I was born in Ambon. I study in Kendari. My mother is Javanese, and my father is Tolakinese. We use Bahasa Indonesia.

Ajam : So what nationality are you?

Ruli : Jatol sir. Javanese and Tolakinese

Ajam : Wkwkwkw

Data (10)

Location : Language centre room

Context : A conversation between two lecturers in the administration office of Sharia faculty.

Izzah : Who has Jaka?

Mudi : There is no Jaka here sir.

Hanu : This one. I see the person, Jaka means janda kaya or rich widow wkwkwkwk

Data (11)

Location : Language centre room

Context : A conversation between two lecturers about the old photo with Marisa Haque

Izzah : Look at the photo. With whom Marisa here?

Marda : The dean mem.

Izzah : Oh 
Marda : She is Marisa too. Mari kita santai..wkwkwkw

Data (12)

Location : Language centre room

Konteks : A conversation during guess lecturer between moderator and presenter at a mini hall of IAIN Kendari.

Izzah : You are still beautiful

Maris : Alhamdulillah

Izzah : But not jelita

Maris : What is it?

Izzah : jerawat lima tahun...wkwkwkwkwkw

Based on the data above, abbreviation is found in data (7), and an acronym is found in data 8-12. The abbreviation of PP and PA on data (7) which initially mean government regulations and academic counselors were misconceptions of their meaning to be 'a woman's vital organ' and 'stupid', respectively. This makes the listeners laugh. On the other hand, the acronyms in the data (8-12) are found in the data of akper (8), jatol (9), jaka (10), marisa (11), and jelita (12). This acronym is imperceptible, and it is pronounced in other words resulting in humor. Akper which initially means a nursing academy turned into a virginity academy, jatol became Javanese Tolaki, jaka which initially refers to a name of the person becoming a rich widow, Marisa which initially points out the name of a certain person turning out to be 'let's relax'. Jelita, which was originally supposedly pretty spelt out turned out to be the meaning of a five-year acne. Of course, the emergence of this laughter is not necessarily present but is supported by the context and atmosphere of the conversation.

Data (1-12) seems funny and makes the listener happy and delightful. However, the degree of pleasure and happiness is only at that moment and does not continue in the next phase. In a psychological perspective, this happiness is called subjunctive happiness. Humor created by lecturers at State Islamic Institute of Kendari is classified as affiliative humor as one of adaptive humor from a psychological perspective. This is because humor is created to refresh our mind, strengthen friendship, improve bonding, and build communication between one lecturer and another. This data is supported by one in-depth interview with one of the RS lecturer who points out that

"Humor is important in the life of a lecturer. With humor, a lecturer can rid himself of any tension. Humor is also one of the easiest and cheapest means of refreshing. Just by playing the use of words alone, one can laugh and be happy. Consequently, the intensity to meet fairly high and interpersonal relationships can be better and can affect the working relationship between one another. Importantly, the humor material is good, not offensive 
and even embarrassing to others. I am a person who likes to humor others. "

In addition, one of AH's senior lecturers who also has a high sense of humor says that

"Humor can indeed make the listener laugh and happy. However, the person's level of pleasure varies. Humor is just one way to make people happy. This is because the size of one's happiness and pleasure varies from one to another. Some are happy with having a decent car and house; some are happy and satisfied with high salaries, others are happy to help people in distress and difficulties. Thus, it can be said that humor played an important role in making someone happy and pleased even though the percentage of about 20 percent. As a result of this humor, interpersonal relationships are improving and resulting in better working relationships between one lecturer and another."

Based on previous interview data, it can be said that humor can reduce highstress levels and enhance the quality of friendship, refresh mind, brainstorm and entertain. It begins with the play of words the lecturers invented when joking with other professors.

\section{Discussion}

This research explains that from a linguistic perspective, humor can be created by using words game. The words can be polysemy and homonymy. We can observe the use of data that has been previously submitted. The word 'beautiful' that was originally perceived as beautiful once spelt into a five-year acne. The word 'Moroccan' for example initially is regarded as the name of a State but can refer to be a smoking activity which can cause people heart disease and so forth. This then makes the listener laugh. As a result, the audience is happy, although it must be admitted that not everyone who laughs can feel good.

This research is in line with some of other studies that examine humor in a linguistic perspective. In their research, Andini (2014) and Anisa (2016) reveals that the discourse of humor in Sentilun Sentilan also uses language games. One of the language games used is the coercion. The language game is largely or dependent on the game of ambiguity created and combined in such a way through various forms of linguistic manipulation at various levels. Usefulness of the prosecution is done to cause a funny effect. Coercion is a matter of interpretation of speech. Rohmadi (2010) illustrates that the prosecutor is the most popular means when connected with language creations. This is because in the coercion there is a lack of logic and unpredictability that comes from conflict and is the trigger of the antics of humor created by the creator. Humor information is contradictory or ambiguous. The forms of coercion include phonetic imposition, such as sound pronunciation and language sound substitution, lexical coercion such as polysemy and homonym, grammatical coercion such as an amphibian phrase, deviation of the form of proverb and deviation of idiom form. 
Rohmadi's research (2010) also asserts that humor is just a play on words. Though just a play on words, people will not leave humor alone, whether children, teenagers, or adults. This is because everyone needs humor in both verbal and nonverbal communication. Creation of humor can utilize writing, drawing and writing, words, various sounds, cartoons (Wijana, 2002) and pornographic associations (Yuniawan, 2005). Nevertheless, humor does not always make people smile and laugh. Sometimes people who listen to humor feel happy and amused, and sometimes feel unhappy. In fact, humor that is out of place can lead to a furious, hateful, insulted, even offended audience that may result in conflict. This is due to the diverse context of humor in each communication depending on the purpose created. Therefore, humor should always be adapted to the conditions and situations between the creator and the audience so that it can entertain and enliven the atmosphere in communicating because humor can relieve stress. So, indeed, the situation and context of the conversation play an important role in creating humor that can make the listener feel happy and joyful.

In a psychological perspective, the joy and happiness of listening to humor do not depend on the language game, the situation and the context of the conversation as it is in the linguistic perspective in most of the humor research in Indonesia, but it depends on quantitative measures. Happiness due to humor that is considered funny is measured on a certain scale, such as Humor Style Questionnaire, Online Standardize Questionnaire,Maslach Burnout Inventory, and Coping Humor Scale (Holmes \& Marra, 2002; Martin et al. 2003; Liu, 2012; Dick \&Holtzman, 2013; Cann \& Collette, 2014; Ford et al., 2014; Yue et al., 2014; Kurtz \& Algoe, 2015; Ford et al., 2017). The humor scale is not only used to measure the humorous humor level, but it is also used to know how the relationship humor with happiness, as well as the relationship of humor with interpersonal relationships and work patterns. These studies show that humor has a positive relationship with happiness and interpersonal relationships if the content of humor is not offensive, aims for pleasure and not humiliation. The better the interpersonal relationship is, the better the working relationship is. In the perspective of psychology, this humor is called affiliative humor and self-enhancing humor. Conversely, if humorous content is hateful, malevolent, insulting, offensive, then it has a negative relationship with happiness and interpersonal relationships. The worse the interpersonal relationship is, the worse the working relationship becomes.

Furthermore, happy and joyful feelings for humor are not only measured by a certain humor scale but are also determined and influenced by a country's culture, such as a comparison of humor studies conducted in the USA and the Arab World such as Egypt and Lebanon. In the United States, for example, self-defeating humor and self-enhancing humor will be more ubiquitous. It is due to the country has low power distance, so the status of difference between people are less. Regarding status, utilizing self-defeating humor is less to lose. Utilizing self-defeating humor could assist in equalizing people both in groups and organizations. To make more equal to other Americans, the presidents are famous for utilizing self-defeating humor (Kalliny, Cruthirds, \& Minor, 2006). Self-enhancing humor is also utilized in more Americans because the culture is more individualistic. Individuality is similar to selfenhancing humor (Kalliny, Cruthirds, \& Minor, 2006). Otherwise, affiliative humor 
will be more common in Arab culture. This is because the Arab world has collectivistic cultures and permanents belong to a group. Affiliative humor is similar to this goal by helping one becomes part of the group (Kuiper, Kazarian, Sine \&Bassil, 2010).

A similar study was also conducted by Tumkaya (2007) on the relationship of humor to the saturation level of lecturers in Turkey. The result indicates that how to overcome the saturation by using humor between fellow lecturers did not show significant results. It also means that humor simply cannot make a person relax and enjoy. In fact, Tumkaya's research results are in line with Porterfield (1987) who says that humor does not reduce stress effects, but has a direct relation with depression. Otherwise, Thorson et al. (1997) determine a negative relation between humor and depression.

In contrast to other, research conducted Nevo, Nevo\& Yin in Singapore (2001) and $\mathrm{Wu}$ and Chan (2013) in China indicates humourless and seem not to enjoy humor. Humor is often utilized to show funny things, to clinch the argument, to illustrate a concept, to prove a point. Humor is considered an inferior form of aesthetic expression and used in a suppressed manner in Chinese culture. This is due to Confucian teaching argues that keeping the proper behavior of social interactions between teacher and students is a must. This teaching has led to the de-emphasis of humor in daily communications.

Finally, this research confirms that the humor created by lecturers at State Islamic Institute of Kendari is affiliative humor that has a positive correlation with happiness even though it occupies only a fairly small percentage. Happiness then affects the pattern of interpersonal relationships so that the effect on the pattern of working relationships. All of this begins with the creation of humor by using words of words, such as polysemy and homonymy.

\section{Conclusion}

Humor is one means to create joyful atmosphere so that it can make the listener laugh. Laughter is a gift from God to man. With a laugh, a lecturer can be free from the pressures of everyday life. With a laugh, a lecturer can be happy and delightful. With a laugh, a lecturer can establish good communication, good interpersonal relationships that also impact on good working relationships. From a linguistic perspective, humor can be created through the play of words containing polysemy and homonymy. This is because both of these aspects can be easily manipulated and cluttered. As a result, pleasure and happiness arise. Happiness occurs because the content, situation, and context of a conversation in humor are also very supportive. From the perspective of psychology, happiness exists because humor is quite an affiliative humor. This happiness then affects interpersonal relationships between a lecturer and another lecturer so that it ultimately affects the pattern of working relationship. The better the humor is, the happier the listener to listen, and the better the pattern of working relationships will become.

An advanced research is an interesting thing to do. Further research can complement existing research using two methods simultaneously, qualitative and quantitative methods. Quantitative methods are performed using a humor scale, such as the Humor Style Questionnaire and quantitative methods done by 
reproducing in-depth interviews. The result will reveal how the relation of humor with happiness and how the relation of humor to the working relationship. In addition, the study object can be expanded by using research samples not only lecturers at State Islamic Institute of Kendari, but also from lecturers at other Islamic universities in Indonesia.

\section{References}

Alavinia, P. (2017). Humor in the Classroom: A Guide for Language Teachers and Educational Researchers, Nancy D. Bell \&. Iranian Journal of Language Teaching Research, 5(2), 137-140.

Alifianita, T., Lukmantoro, T., Sos, S., \& Si, M. (2016). Language Games in ask. fm Conversations. Interaksi Online, 4(4), 1-11.

Anisah, Z. (2016). Polisemi Pada Wacana Humor Indonesia Lawak Klub. Al Hikmah: Jurnal Studi Keislaman, 6(2).

Andini, I. (2014). Ketaksaan Tindak Tutur Dalam Wacana Humor Pada Acara Sentilan Sentilun Di Metro TV. Bahtera: Jurnal Pendidikan Bahasa dan Sastra, 13(1), 11-19.

Banas, J. A., Dunbar, N., Rodriguez, D., \& Liu, S. J. (2011). A review of humor in educational settings: Four decades of research. Communication Education, 60(1), 115-144.

Cann, A., \& Collette, C. (2014). Sense of humor, stable affect, and psychological wellbeing. Europe's Journal of Psychology, 10(3), 464-479.

Carroll, N. (2014). Humour: A very short introduction. OUP Oxford.

Chefneux, G. (2015). Humour at work. Language and Dialogue, 5(3), 381-407.

Cruse, A. (2011). Meaning in language: An introduction to semantics and pragmatics.

Dyck, K. T., \&Holtzman, S. (2013). Understanding humor styles and well-being: The importance of social relationships and gender. Personality and Individual Differences, 55(1), 53-58.

Ford, T. E., McCreight, K. A., \& Richardson, K. (2014). Affective style, humor styles and happiness. Europe's Journal of Psychology, 10(3), 451-463.

Ford, T. E., Lappi, S. K., O' Connor, E. C., \& Banos, N. C. (2017). Manipulating humor styles: Engaging in self-enhancing humor reduces state anxiety. Humor, 30(2), 169-191.

Friedman, S. (2011). The cultural currency of a 'good' sense of humour: British comedy and new forms of distinction. The British Journal of Sociology, 62(2), 347370.

Gunawan, F. (2016). The Deviation of Pragmatic Aspects of Lecturer Humor Discourse at IAIN Kendari. Proceedings ofInternational Conference of Linguistics (SETALI): Language analysis from forensic linguistics (pp. 173-178). Bandung: Indonesia University of Education. 
Gunawan, F., \& Wahyuni, I. (2017). Utilizing humor among teaching colleagues and its effect on their happiness in Islamic higher education of Indonesia. Proceedings of AICS-Social Sciences, 7, 633-642.

Hairuddin, A., Gani, M. U., Sinring, B., \& Arifin, Z. (2017). Motivation, Competence and Organizational Commitment's Effect on Lecturers' Job Satisfaction and Lecturers Performance. Social Sciences, 6(03).

Hampes, W. (2016). The relationship between humor styles and forgiveness. Europe's Journal of Psychology, 12(3), 338.

Holmes, J., \& Marra, M. (2002). Having a laugh at work: How humour contributes to workplace culture. Journal of Pragmatics, 34(12), 1683-1710.

Kalliny, M., Cruthirds, K. W., \& Minor, M. S. (2006). Differences between American, Egyptian and Lebanese humor styles: Implications for international management. International Journal of Cross Cultural Management, 6(1), 121-134.

Kuiper, N. A., Kazarian, S. S., Sine, J., \& Bassil, M. (2010). The impact of humor in North American versus Middle East cultures. Europe's Journal of Psychology, 6(3), 149-173.

Kurtz, L. E., \&Algoe, S. B. (2015). Putting laughter in context: Shared laughter as behavioral indicator of relationship well-being. Personal Relationships, 22(4), 573590 .

Kusno, A. (2014). Permainan Bahasa Pada Humor Cak Lontong (Sebuah Tinjauan Sosiolinguistik). Lingua, 10(2).

Lebowitz, K. R., Suh, S., Diaz, P. T., \& Emery, C. F. (2011). Effects of humor and laughter on psychological functioning, quality of life, health status, and pulmonary functioning among patients with chronic obstructive pulmonary disease: a preliminary investigation. Heart $\mathcal{E}$ Lung: The Journal of Acute and Critical Care, 40(4), 310-319.

Li, J. (2015). Humor in the Hong Kong Language Classroom: Students' Perceptions (Doctoral dissertation), Department of English, The Hong Kong Polytechnic University.

Liu, K. W. (2012). Humor styles, self-esteem and subjective happiness. Humour, 1, 2141.

Maiolino, N. B., \& Kuiper, N. A. (2014). Integrating humor and positive psychology approaches to psychological well-being. Europe's Journal of Psychology, 10(3), 557-570.

Martin, R. A., Puhlik-Doris, P., Larsen, G., Gray, J., \& Weir, K. (2003). Individual differences in uses of humor and their relation to psychological well-being: Development of the Humor Styles Questionnaire. Journal of Research in Personality, 37(1), 48-75.

Martin, R. A., \& Ford, T. (2018). The psychology of humor: An integrative approach. Academic press. 
Miles, M. B., Huberman, A. M., \& Saldana, J. (2014). Fundamentals of qualitative data analysis. Qualitative data analysis: A methods sourcebook, 69-104.

Nayyar, R., \& Zeeshan, M. (2017). MPhil Scholars' Views about the Use of Humor in English Language Classroom in Quetta, Balochistan, Pakistan. International Journal of English Linguistics, 7(2), 134.

Ofra Nevo, Ofra, Nevo Baruch, Yin, Janie Leong Siew. (2001). Singaporean humor: A cross-cultural cross-gender comparison. The Journal of General Psychology, 128 (2), pp.143

Porterfield, A. L. (1987). Does sense of humor moderate the impact of life stress on psychological and physical well-being? Journal of Research in Personality, 21, 306317

Puspitasari, D. A. (2013). Humor dalam kumpulan buku kartun "Benny \& Mice" (Suatu Kajian Pragmatik). Suluk Indo, 2(2), 1-15.

Richards, K. (2010). Professional orientation in back region humor. Text $\mathcal{E}$ Talk-An Interdisciplinary Journal of Language, Discourse \& Communication Studies, 30(2), 145-167.

Rohmadi, M. (2010).Strategi Penciptaan Humor dengan Pemanfaatan Aspek-aspek Kebahasaan .Humaniora, 22(3), 285-298.

Satta, M. (2018). A linguistic grounding for a polysemy theory of 'knows'. Philosophical Studies, 175(5), 1163-1182.

Stieger, S., Formann, A. K., \& Burger, C. (2011). Humor styles and their relationship to explicit and implicit self-esteem. Personality and Individual Differences, 50(5), 747-750.

Thomas, J. A. (2014). Meaning in interaction: An introduction to pragmatics. Routledge.

Thorson, J. A., Powell, F. C., Sarmany-Schuller, I., \& Hampes, W. P. (1997). Psychological health and sense humor. Journal of Clinical Psychology, 53 (6), 605619.

Tümkaya, S. (2006). Faculty Burnout in Relation to Work Environment and Humor as a Coping Strategy. Educational Sciences: Theory E Practice, 6(3).

Usman, B., Silviyanti, T. M., \& Marzatillah, M. (2016). The Influence of Teacher's Competence towards the Motivation of Students in Learning English. Studies in English Language and Education, 3(2), 134-146.

Vetter, B., \& Viebahn, E. (2016). How many meanings for 'may'? The case for modal polysemy. Philosophers' Imprint, 16(10), 1-26.

Wijana, I. D. P. (2002). Angka, Bilangan, dan Huruf dalam Permainan Bahasa. Humaniora, 12(3), 271-277.

Wijaya, I. D. P \& Rohmadi, M. (2010). Analisis Wacana Pragmatik Kajian Teori dan Analisis. Surakarta: Yuma Pustaka. 
Wilujeng, N. C. S. (2013). Language Play: An Overview. Jurnal Kebahasaan dan Kesastraan Multilingual, 2, 215-228.

Wu, J., \& Chan, R. (2013). Chinese teachers' use of humour in coping with stress. International Journal of Psychology, 48(6), 1050-1056.

Yue, X. D., Liu, K. W. Y., Jiang, F., \&Hiranandani, N. A. (2014). Humor styles, selfesteem, and subjective happiness. Psychological Reports, 115(2), 517-525.

Yuliawati, S. (2012). Kajian Implementasi Tri Dharma Perguruan Tinggi Sebagai Fenomena Pendidikan Tinggi di Indonesia. Jurnal Ilmiah Widya.

Yuniawan, T. (2005). Teknik Penciptaan Asosiasi Pornografi dalam Wacana Humor Bahasa Indonesia. Jurnal Humaniora, 17(3), 285-292. 